\title{
Nikotinplaster for røykeslutt under svangerskap?
}

\section{Røyking i svangerskapet er forbundet med prematur fødsel og lav fødselsvekt. Gir bruk av nikotinplaster hos gravide økt sannsynlighet for røykeslutt?}

I en ny multisenterstudie fra Storbritannia har forskere undersøkt om nikotinplaster kan bidra til røykeslutt hos gravide (1). Studien omfattet 1052 kvinner i svangerskapsuke $12-24$. De ble randomisert til behandling med nikotinplaster eller placebo. I tillegg fikk de veiledning.
Det var ingen signifikant forskjell mellom de to gruppene når det gjaldt andelen som ble røykfrie frem til fødselen. Med unntak av flere keisersnitt i gruppen som fikk nikotinplaster, fant man heller ingen forskjeller i svangerskapsutfall. Det var imidlertid lav etterlevelse i begge gruppene.

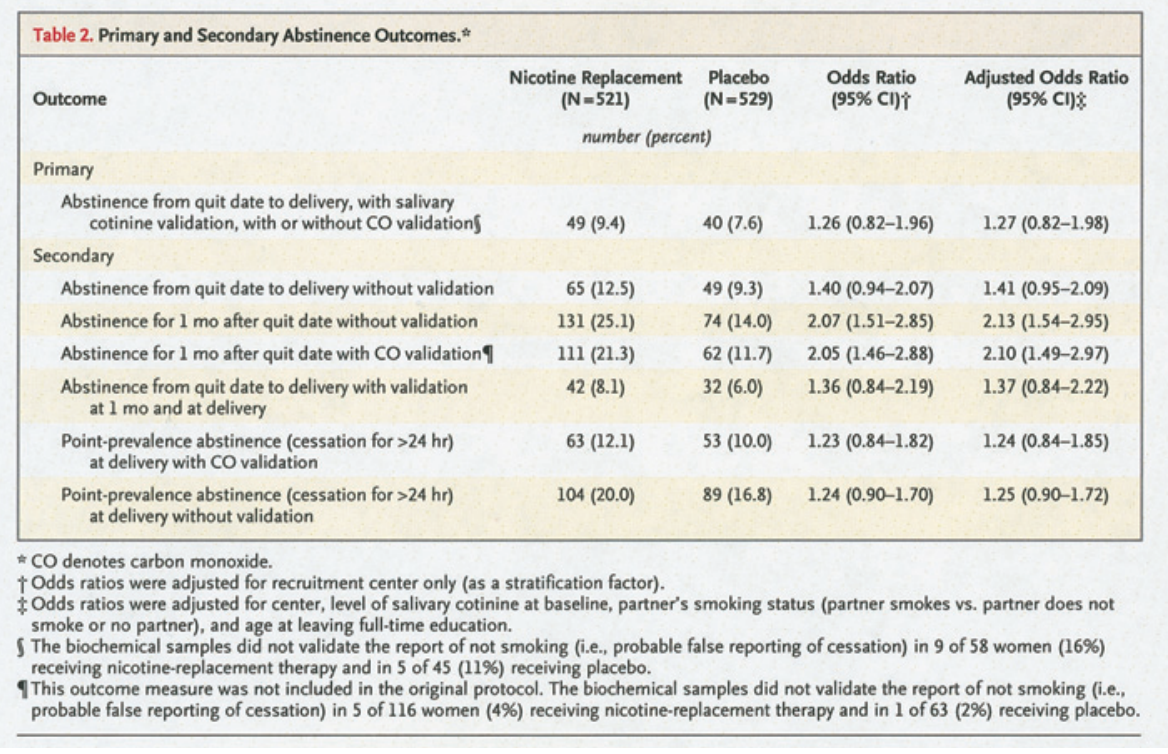

Gjengitt med tillatelse fra New England Journal of Medicine (1)
- Hovedkonklusjonen i denne studien er at bruk av nikotinpreparater fra 12.-24. uke i svangerskapet $i$ tillegg til personlig veiledning ikke førte til at flere gravide ble røykfrie ut svangerskapet. Det er imidlertid flere momenter som kan så tvil om dette er resultater man også må regne med i daglig praksis, sier overlege Frode Gallefoss ved Lungeavdelingen, Sørlandet sykehus Kristiansand.

- Forfatterne nevner selv en dårlig etterlevelse med nikotin-/placeboplasteret - henholdsvis $7 \%$ og $3 \%$. Dette er overraskende lavt og kan avspeile at den personlige oppfølgingen fra helsepersonell har vært mangelfull. Et annet moment er intervensjonstidspunktet. Studier viser at de som spontant blir røykfrie i svangerskapet, slutter nokså umiddelbart etter at de er blitt klar over graviditeten. Flere tidligere studier på effekter av røykeintervensjon, for eksempel ved ultralydkontroll omkring18. svangerskapsuke, har også vist skuffende resultater.

I omsorgen for røykende gravide er det viktig at tidlig røykeintervensjon etterfølges av tett personlig oppfølging. Da kan det hende at nikotinpreparater kan bidra til økt røykeslutt hos gravide, sier Gallefoss.

\section{Merete Kile Holtermann \\ merete.holtermann@legeforeningen.no Tidsskriftet \\ Litteratur \\ 1. Coleman T, Cooper S, Thornton JG et al. A ran- domized trial of nicotine-replacement therapy pat- ches in pregnancy. N Engl J Med 2012; 366 . 808- 18 .}

\section{Kunstgruppeterapi ved schizofreni?}

\section{Det er uklart om gruppebasert kunstterapi som tilleggsbehand- ling ved schizofreni har effekt på sosial fungering og mental helse.}

Internasjonale retningslinjer for behandling av schizofreni og relaterte psykoser anbefaler en kombinasjon av farmakoterapi og psykososiale intervensjoner. Britiske forskere har nå utført en multisenterstudie for å evaluere den kliniske effekten av kunstterapi i grupper for schizofrenipasienter sammenliknet med annen aktivitet og standard behandling (1).

Totalt 417 personer over 18 år med diagnosen schizofreni deltok i studien. De ble randomisert til tre grupper. Den første fikk tilbud om ukentlig gruppebasert kunstterapi i 12 måneder i tillegg til standard omsorg, den andre fikk et tilsvarende opplegg, men med gruppeaktiviteter som ikke omfattet kunstnerisk aktivitet, den tredje fikk kun standardbehandling. Kunst- og aktivitetsgruppene besto av inntil åtte pasienter, og terapien varte i 90 minutter hver gang.

Det var ingen forskjeller i global fungering eller mental helse i de tre gruppene. Det var heller ingen forskjell i fremmøte, sosial fungering og tilfredshet med omsorgen.

- Det er vanskelig å gjennomføre denne type undersøkelser, så tiltaket er prisverdig, sier professor Stein Opjordsmoen Ilner ved Enhet voksenpsykiatri ved Universitetet i Oslo. - Resultatene bør tolkes med varsomhet. Pasientene hadde en gjennomsnittsalder på 41 år og hadde vært syke i 17 år i gjen- nomsnitt. Deltakelsen i gruppene var svært lav, og mange møtte ikke i det hele tatt. Dersom man skal undersøke effekten av en tilleggsbehandling, må den gis i tilstrekkelig dose.

Kunstterapi kan være nyttig for enkelte pasienter, kanskje særlig tidlig i sykdomsforløpet, sier Ilner. - Også andre kreative tilnærminger, slik som bevegelsesgrupper og musikkterapi, bør undersøkes nærmere, sier han.

Trine B. Haugen

trine.b.haugen@hioa.no

Tidsskriftet

\footnotetext{
Litteratur

1. Crawford MJ, Killaspy H, Barnes TR et al. Group art therapy as an adjunctive treatment for people with schizophrenia: multicentre pragmatic randomised trial. BMJ 2012; 344: e846.
} 